\title{
GRAFT TAKES OF TOMATO ON OTHER SOLANACEOUS PLANTS ${ }^{1}$
}

\author{
ANDRÉ RICARDO ZEIST ${ }^{2 *}$, JULIANO TADEU VILELA DE RESENDE ${ }^{2}$, CLEVISON LUIZ GIACOBBO $^{3}$, CACILDA $^{2}$ \\ MARIA DUARTE RIOS FARIA ${ }^{2}$, DIEGO MUNHOZ DIAS ${ }^{2}$
}

\begin{abstract}
This paper aimed to assess tomato grafting on different solanaceous species through two grafting methods. Scions were cut from cultivar Santa Cruz Kada seedlings. A fully randomized experimental design was carried out with treatments in a $9 \times 2$ factorial scheme. As rootstocks, four accessions of mini-tomatoes (0224-53, RVTC 57, RVTC 20 and 6889-50 - Solanum lycopersicum L); two species of wild tomato (Solanum habrochaites var hirsutum 'PI-127826' and Solanum pennellii 'LA716'); other two tomato species [Solanum, cocona (Solanum sessiliflorum) and physalis (Physalis peruviana)] and a control with cultivar Santa Cruz Kada (auto-graft) rootstocks were used. In addition, two grafting methods were evaluated full cleft and approach graft. Fifteen days after grafting, plants were assessed for graft-take percentage; root length; plant height; leaf number; foliar area; root, stem and leaf dry matter; and ratio between shoot and root dry matter. Based on the results, we may state rootstock and grafting interaction had effect on both graft-take rate and plant development. Overall, the studied plants should be recommended as rootstock, except for 6889-50 mini-tomato (S. lycopersicum L.) and S. pennellii. Full cleft grafting was most suitable for cocona and physalis, while the approach method showed better results for the mini-tomato accessions 0224-53, RVTC 57 and RVTC 20, as well as for S. habrochaites.
\end{abstract}

Keywords: Solanum lycopersicum. Solanum pennellii. Solanum habrochaites. Graft methods.

\section{PEGAMENTO DE ENXERTOS DE TOMATEIRO EM DIFERENTES SOLANÁCEAS}

RESUMO - O presente trabalho teve como objetivo avaliar o pegamento de enxertia de tomateiro, em diferentes espécies de solanáceas e por diferentes métodos de enxertia. Foram produzidas para enxerto mudas de tomateiro da cultivar Santa Cruz $\mathrm{Kada}^{\circledR}$. O delineamento experimental utilizado foi o inteiramente casualizado, com os tratamentos arranjados em esquema fatorial 9 x 2, avaliando-se como porta-enxerto: os acessos de minitomate 0224-53, RVTC 57, RVTC 20 e 6889-50 (Solanum lycopersicum L); as espécies silvestres de tomateiro Solanum habrochaites var hirsutum 'PI-127826' e Solanum pennellii 'LA716'; duas outras espécies Solanum, cubiu (Solanum sessiliflorum) e fisales (Physalis peruviana); e o tomateiro cultivar Santa Cruz Kada ${ }^{\circledR}$ como testemunha (auto-enxertia), e avaliados dois métodos de enxertia: fenda cheia; e encostia. Aos quinze dias após a enxertia, as plantas foram avaliadas quanto ao: índice de pegamento de enxertia; comprimento de raiz; altura das plantas; número de folhas; área foliar; massa seca das raízes, do caule e das folhas; e relação massa seca da parte aérea/massa seca das raízes. Com base nos resultados obtidos, foi possível verificar que o índice de pegamento e o desenvolvimento vegetativo das plantas após a enxertia em tomateiro foi influenciado significativamente pela interação (porta-enxerto x método de enxertia). Dentre os porta-enxertos avaliados, todos podem ser recomendados, exceto o acesso de minitomate 6889-50 ( $S$. lycopersicum L.) e a espécie $S$. pennellii. Para os porta-enxertos cubiu e fisales recomenda-se a utilização do método de enxertia por fenda cheia, e para os porta-enxertos acesso de (minitomate 0224-53, RVTC 57 e RVTC 20; e espécie $S$. habrochaites) o método de encostia.

Palavras-chave: Solanum lycopersicum. Solanum pennellii. Solanum habrochaites. Métodos de enxertia.

\footnotetext{
*Corresponding author

${ }^{1}$ Received for publication in $07 / 20 / 2015$; accepted in $08 / 22 / 2016$.

Paper extracted from the Master's dissertation of the first author.

${ }^{2}$ Department of Agronomy, Universidade Estadual do Centro-Oeste do Paraná, Guarapuava, PR, Brazil; andre.zeist@bol.com.br, jresende@unicentro.br, criosfaria@hotmail.com,diegomunhozdias@hotmail.com.

${ }^{3}$ Department of Agronomy, Universidade Federal da Fronteira Sul, Chapecó, SC, Brazil; clevison.giacobbo@uffs.edu.br.
} 


\section{INTRODUCTION}

Among vegetable crops, tomato is the most widespread, being one of major crops within agribusiness marketing, highly consumed worldwide both fresh or processed. Brazil, according to the FAO (2012), holds the eighth place in the ranking of fresh tomato world production, yielding nearly four millions of tons within 71 thousand hectares. Before it comes China, as the major worldwide producer, followed by India, United States of America, Turkey, Egypt, Iran and Italy.

Despite its prominence, several factors can limit tomato production, such as adverse weather conditions, pests and diseases (VENEMA et al., 2008; MIRANDA et al., 2010; CARRER FILHO et al., 2015). To overcome some of these hurdles, farmers rely on grafting technique, which consists in bonding parts of two plants by means of tissue regeneration developing a single plant (PEIL, 2003; CARDOSO et al., 2006; LOOS; CALIMAN; SILVA, 2009; SIRTOLI et al., 2011). Such tool make use of root systems (rootstocks) that are resistant, enabling control of diseases and pests related to the soil (LIN et al., 2008; RIVARD et al., 2012; GILARDI; GULLINO; GARIBALDI, 2013).

Because of the need for studies to find rootstocks showing chemical, morphological and physiological affinity with tomato scions, providing resistance to adverse soil and climate conditions, the testing of different solanaceous plants becomes essential to check their potential (FARIAS et al., 2013; PETRAN; HOOVER, 2014). By means of molecular biology techniques, it is observed that grown tomato plants show limited genetic diversity, while wild species and Genbank accessions have higher variability and diversity, thus presenting resistance to weathering, pests and pathogens (GARCIA-MARTINEZ et al, 2005; TAM et al., 2005; VENEMA et al., 2008). Thus, it is believed tomato grafting on wild species or accessions is important for a direct use of genes, enabling yield improvement and fruit quality traits, besides promoting tolerance/ resistance to various biotic and abiotic factors (VENEMA et al., 2008; LEE et al., 2010).

One of the wild species of greatest interest is Solanum pennelli, it has tolerance to water deficit (EASLON; RICHARDS, 2009) and has high resistance to isolates of three strains of Fusarium oxysporum $f$. $s p$. lycopersici (CARRER FILHO et al., 2015). Another is Solanum habrochaites, which is adapted to a wide range of latitudes, enhancing tomato growth, even under unfavorable conditions, throughout the cycle if compared to ungrafted plants (VENEMA et al., 2008), as well as providing resistance to Verticillium dahlia, strains 1 and 2 (MIRANDA et al., 2010).

Other prospective rootstocks are the mini-tomato accessions $0224-53,6889-50$ from the
Germplasm Bank of Vegetables in the Federal University of Viçosa, and RVTC 57 and RVTC 20 from the bank of the State University of the Midwest (Brazil). In spite of their poor quality fruits, they own interesting characteristics to be used as rootstocks, such as vigorous root system, good growth rate and tolerance to adverse soil and weather conditions. Solanum species such as scarlet eggplant, cocona, jurubeba and others can also be evaluated as rootstocks, also aiming to increase protection against soil pathogens (LOPES; BOITEUX; ESCHEMBACK, 2015).

Tissue affinity between rootstock and scion comprises morphological, physiological and chemical aspects of the plants (CANIZARES; GOTO, 2002; SIRTOLI et al., 2008). Grafting success or failure is closely related to graft-union healing process. Among the influencing factors on healing of grafted plants, we may highlight the used grafting method and the acclimatization of seedlings (LEE et al., 2010).

Grafting method has great effect on take rates. Even if the approach method is highly widespread for tomatoes, full cleft grafting is most suitable and broadly used. However, the most appropriate method for vegetables should be evaluated through the rate of takes and graft compatibility, in which results may vary depending on rootstock/ scion relationship used match (LEE, 1994; MOHAMED et al., 2014).

Given the above information, this study aimed to evaluate take rate of tomato grafted on different species of nightshades by two grafting methods.

\section{MATERIAL AND METHODS}

The experiment was performed at the Division of Olericulture, Department of Agricultural Sciences, State University of the Midwest (Universidade Estadual do Centro-Oeste UNICENTRO). It is located in the city of Guarapuava - PR, Brazil, at $25^{\circ} 41^{\prime}$ S latitude, $51^{\circ} 38^{\prime} \mathrm{W}$ longitude and $1,100 \mathrm{~m}$ altitude. The local climate is classified as $C f b$ (mesothermal humid subtropical) by Köppen's classification, temperate, without dry season, with hot summer and mild winter (WREGE et al. 2011).

Seedlings of the cultivar Santa Cruz Kada were used as source of scion material. The experiment followed a fully randomized design with treatments in a $9 \times 2$ factorial scheme, with three replications and ten grafted plants each. Different species belonging to the Solanaceous family. Among them, four accessions of mini-tomatoes (0224-53, RVTC 57, RVTC 20, and 6889-50) (Solanum lycopersicum L.); four species of wild tomatoes $[S$. habrochaites var hirsutum 'PI-127826', S. pennellii 'LA716', cocona ( $S$. sessiliflorum), and physalis $(P$. peruviana)]; and cultivar Santa Cruz Kada as 
control. Grafting process was carried out by two different methods full cleft (FC) and approach graft (AG).

Cultivar Santa Cruz Kada was also used as rootstock for frank evaluation of graft take. Low take rates would point out whether the method or the environment were responsible for underachievement of results, instead of a miss of morphological/ physiological affinity between scion and rootstock.

Seedlings grown in a greenhouse gave rise to the stock plants. Rootstock and scion sowing was made on 200-cell polystyrene trays, filled up with bio-stabilized pine bark. Roots were maintained in floating hydroponics for 24 days. Cocona and physalis rootstocks were sown thirty days before their scions. While rootstocks of the specie $S$. habrochaites and $S$. pennellii were sown ten days before theirs. As for the mini-tomatoes rootstock, seeding was performed with scions and control. Such distinctive sowing dates arise from each of them show different emergence and growth time. For proper amounts of seedlings, two seeds were sown in each cell for both rootstocks and scions. Later, between four and five days after emergence, seedlings were thinned out, leaving only one per cell.

At 19 days after emergence (DAE), seedlings were transplanted to $180-\mathrm{mL}$ plastic pots, placing two plants per pot (one rootstock and one scion -1 : 1), aiming to provide a larger amount of substrate, increase growth, development and bring two plants together for approach grafting.

Grafting was made at 24 DAE (Oct. 31/2013), when seedlings had three to four true leaves. In doing this, carbon steel blades (tissue cutting), biodegradable tape (stem fixing) and a wooden rod (support) were used to reduce seedling stress from the grafting process. After grafting, plants were left in a moist chamber of floating type, set on a bench inside the greenhouse, aiming to enhance the number of takes.

This moist chamber was composed of a low tunnel (4.5 m long x $1.20 \mathrm{~m}$ wide and $0.75 \mathrm{~m}$ high), with its central part covered by ultraviolet transparent film, and its base lined by a black polyethylene film. On top of this base, a water depth between 0.02 to $0.04 \mathrm{~m}$ in height filled the bottom, remaining during take of grafts.

During assessment, thermometers recorded daily maximum $\left(\mathrm{T}_{\max }\right)$ and minimum $\left(\mathrm{T}_{\min }\right)$ temperatures inside the moist chamber environment, and by arithmetic average between them, the mean $\left(\mathrm{T}_{\text {ave }}\right)$ was calculated. Similarly, the relative humidity (RH) was gauged every day by a digital thermos-hygrometer (Unity HTC-2). In addition, sprayings against pest and pathogens were not carried out, or any other type of plant chemical treatment.

Grafted plants were removed from the chamber 10 days after grafting and, side shoots (suckers) were withdrawn, with later elimination of the top of rootstocks submitted to the approach technique. All plants were placed on the bench inside the greenhouse for acclimatization.

On day 15 after grafting, weaning of scions was performed for plants grafted by the approach method, i.e. they were removed from rootstocks. On the same date, several other assessments were carried out: graft-take rate (GT) - counting of the number of healed grafts in percentage (\%); root length $(\mathrm{RL})$ - measure of the longest root $(\mathrm{cm})$; plant height $(\mathrm{PH})$ - from stem base to the apex $(\mathrm{cm})$; leaf number (LN) - counting of expanded true leaves; foliar area (FA) - measured by a leaf area meter (LI-COR, model LI 3100C) $\left(\mathrm{cm}^{2}\right)$; root dry matter (RDM), stem dry matter (SDM) and leaf dry matter (LDM). For dry matter measurements, material was left in an air-forced circulation oven at $64{ }^{\circ} \mathrm{C}$, for 96 hours, weighing in a $0.001-\mathrm{g}$ precision scale; subsequently, the ratio APDM/ RDM was calculated by the relationship between aerial part dry matter $(\mathrm{LDM}+\mathrm{SDM})$ and root dry matter.

Data were tested for normality and homogeneity and then subjected to analysis of variance by $\mathrm{F}$ test and, when significant, subjected to comparison by the Scott-Knott grouping test at 5\% probability. The data expressed as percentages were transformed into arcsine $(\mathrm{x} / 100)^{1 / 2}$, being analyzed by ASSISTAT software version 7.7 of 2014 (SILVA, 2014).

\section{RESULTS AND DISCUSSION}

During observations, $\mathrm{T}_{\min }$ and $\mathrm{T}_{\max }$ range was between 11.3 to $33.5^{\circ} \mathrm{C}$, with averages of $22.0^{\circ} \mathrm{C}$, and que para $\mathrm{RH}$ varied little, with daily values nearly $85.0 \%$ (Figure 1). These environmental conditions registered inside the chambers are favorable for graft takes. High RH avid dehydration of grafts, and when associated to daily average temperatures of nearly $22^{\circ} \mathrm{C}$ healing process is enhanced (CANIZARES; GOTO, 2002; LEE et al., 2010).

By variance analysis, it was noteworthy a significant interaction between the factors rootstock and graft method for all studied variables (GT, RL, PH, LN, FA, RDM, SDM, LDM, and MSPA/RDM), after 15 days of grafting. Therefore, the combination of both sources influenced either healing process as initial growth of seedlings after being grafted. We found that the best combination changed among the evaluated traits (Table 1, 2 and 3).

For GT, which is the variable of interest concerning graft process, an increase of $33.33 ; 66.66$ and $66.66 \%$ for rootstocks of $S$. pennellii, cocona and physalis, respectively, whether compared to the approach method (Table 1). 


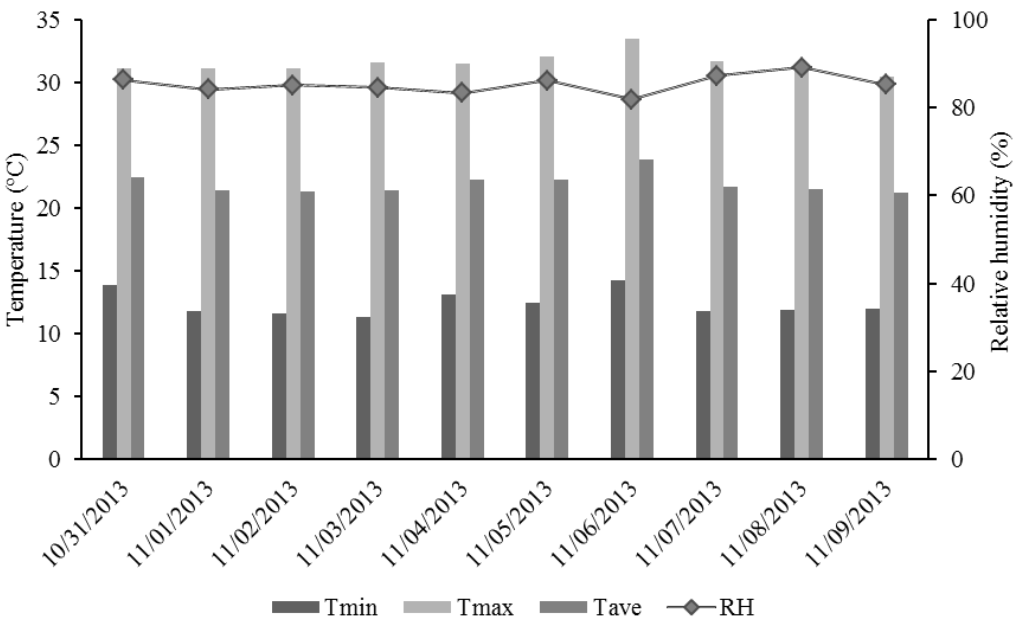

Figure 1. Minimum $\left(T_{\min }\right)$, maximum $\left(T_{\max }\right)$ and average $\left(T_{\text {ave }}\right)$ daily air temperatures and air relative humidity $(R H)$ inside moist chamber throughout graft conditioning.

Graft take consists essentially of the healing process after joining scion and rootstock (PEIL, 2003). This process is triggered by cambial regeneration, from which a callus fills the gap area between rootstock and scion tissues, making a continuous connection between vascular elements of both sides at graft point (MARTÍNEZ-BALLESTA et al., 2010; NOGUEIRA FILHO et al. 2010).

As observed here for $S$. pennellii, cocona and physalis rootstocks, Simões et al. (2014), evaluating several species of nightshades as tomato rootstocks, also observed superior GT rates by using full cleft. Thus, this method might be suitable for repairing of vessels and healing of local connection between rootstock and scion. Conversely, the approach method does not enable a safe recovery of the tissues within this bonding point (SIRTOLI et al., 2011). Canizares and Goto (2002) reported greater survival percentage of cucumber seedlings grafted by full-cleft method, when compared to two other methods.
Even though GT varied depending on the combinations, except for mini-tomato 6889-50, these rates were above $83 \%$, which may be considered a satisfying index. Simões et al. (2014) also reported similar results in Tomato, finding positive results for the following combinations scarlet eggplant on tomato dual and single cleft, jurubebão and tomato via double cleft, and Jurubeba and red tomato via double and single cleft. Cardoso et al. (2006), assessing the feasibility of hybrid Hawaii 7996 as rootstock of commercial cultivars of tomato, observed a GT rate of $93.4 \%$ for all grafts in nursery.

The low GT observed for 6889-50 rootstock restricts its commercial use since it would increase production costs. In both methods, there were losses above $25 \%$ of the grafted seedlings, decreasing thus its production efficiency. According to Peil (2003), not all the combinations (rootstock $\mathrm{x}$ scion) show good rates of take, what may vary with morpho-physiological traits that enable desirable healing levels.

Table 1. Graft-take rate (GT), root length (RL) and root dry matter (RDM) of tomato seedlings grafted on different solanaceous plants through two grafting methods [full cleft (FC); approach graft (AG)], on the 15 day after grafting.

\begin{tabular}{|c|c|c|c|c|c|c|}
\hline \multirow[t]{2}{*}{ Rootstocks } & \multicolumn{2}{|c|}{ GT (\%) } & \multicolumn{2}{|c|}{$\mathrm{RL}(\mathrm{cm})$} & \multicolumn{2}{|c|}{ RDM (g) } \\
\hline & $\mathrm{FC}$ & $\mathrm{AG}$ & $\mathrm{FC}$ & $\mathrm{AG}$ & $\mathrm{FC}$ & $\mathrm{AG}$ \\
\hline $0224-53$ & $91.66 \mathrm{Aa}^{*}$ & $91.66 \mathrm{Aa}$ & $32.11 \mathrm{Ba}$ & $36.84 \mathrm{Aa}$ & $0.50 \mathrm{Ba}$ & $0.58 \mathrm{Aa}$ \\
\hline RVTC 57 & $100.00 \mathrm{Aa}$ & $83.33 \mathrm{Ab}$ & $31.86 \mathrm{Ba}$ & $37.10 \mathrm{Aa}$ & $0.50 \mathrm{Ba}$ & $0.59 \mathrm{Aa}$ \\
\hline RVTC 20 & $100.00 \mathrm{Aa}$ & $83.33 \mathrm{Aa}$ & $32.36 \mathrm{Ba}$ & $36.57 \mathrm{Aa}$ & $0.51 \mathrm{Ba}$ & $0.58 \mathrm{Aa}$ \\
\hline $6889-50$ & $75.00 \mathrm{Ab}$ & $66.66 \mathrm{Ab}$ & $16.40 \mathrm{Bc}$ & 19.24 Ac & $0.26 \mathrm{Bc}$ & $0.30 \mathrm{Ac}$ \\
\hline S. habrochaites & $75.00 \mathrm{Ab}$ & $83.33 \mathrm{Aa}$ & $32.00 \mathrm{Ba}$ & $38.86 \mathrm{Aa}$ & $0.51 \mathrm{Ba}$ & $0.62 \mathrm{Aa}$ \\
\hline S. pennellii & $91.66 \mathrm{Aa}$ & $58.33 \mathrm{Bb}$ & $8.33 \mathrm{Ad}$ & $9.75 \mathrm{Ad}$ & $0.13 \mathrm{Ad}$ & $0.15 \mathrm{Ad}$ \\
\hline Cocona & $100.00 \mathrm{Aa}$ & $33.33 \mathrm{Bc}$ & $25.46 \mathrm{Ab}$ & $27.03 \mathrm{Ab}$ & $0.40 \mathrm{Ab}$ & $0.43 \mathrm{Ab}$ \\
\hline Physalis & $91.66 \mathrm{Aa}$ & $25.00 \mathrm{Bc}$ & $26.13 \mathrm{Ab}$ & $27.24 \mathrm{Ab}$ & $0.41 \mathrm{Ab}$ & $0.43 \mathrm{Ab}$ \\
\hline Control & $100.00 \mathrm{Aa}$ & $100.00 \mathrm{Aa}$ & $16.33 \mathrm{Bc}$ & $19.26 \mathrm{Ac}$ & $0.26 \mathrm{Bc}$ & $0.30 \mathrm{Ac}$ \\
\hline $\mathrm{CV}(\%)$ & \multicolumn{2}{|c|}{19.41} & \multicolumn{2}{|c|}{5.66} & \multicolumn{2}{|c|}{5.76} \\
\hline
\end{tabular}

* Means followed by different letters, uppercase within lines and lowercase within columns, differ from each other by the Scott-Knott's test at 5\%. 
The GT of $100 \%$ found for the control (cultivar Santa Cruz Kada), in both methods, shows that grafting conditions favored healing without interfering with bonding of structures. In addition, this fact enable us inferring that rootstocks that differed from control on this feature had less morpho -physiological affinity if compared with the autograft. This lower affinity between scion and rootstock of other genotypes and/ or species occurs because it is not always possible to make connections between both vascular tissues for healing process, which, occasionally, is because of the incompatibility of the species (MARTÍNEZ-BALLESTA et al., 2010).
RL and RDM, which are directly related to plant growth in post-grafting, stood out for 0224-53, RVTC 57, RVTC 20 and $S$. habrochaites via approach method. For both methods, all rootstocks, except 6889-50 and $S$. pennellii, presented RL values significantly higher than the control (Table 1).

By comparing both sources of variation, we found that the best results for grafting via approach method, compared to full cleft, were obtained for RL and RDM, when using 0224-53, RVTC 57, RVTC 20, 6889-50, S. habrochaites and control (Table 1). In addition, the approach graft showed increasing values of PH and LN for 6889-50, S. habrochaites and $S$. pennellii (Table 2).

Table 2. Plant height (PH), number of leaves (LN) and foliar area (FA) of tomato plants grafted on distinct solanaceous via two different methods [full cleft (FC) and approach graft (AG)], on the 15 day after grafting.

\begin{tabular}{|c|c|c|c|c|c|c|}
\hline \multirow[t]{2}{*}{ Rootstocks } & \multicolumn{2}{|c|}{$\mathrm{PH}(\mathrm{cm})$} & \multicolumn{2}{|c|}{$\mathrm{LN}$} & \multicolumn{2}{|c|}{$\mathrm{FA}\left(\mathrm{cm}^{2}\right)$} \\
\hline & $\mathrm{FC}$ & $\mathrm{AG}$ & $\mathrm{FC}$ & $\mathrm{AG}$ & $\mathrm{FC}$ & $\mathrm{AG}$ \\
\hline $0224-53$ & $12.29 \mathrm{Ab}$ & $12.32 \mathrm{Ab}$ & $3.64 \mathrm{Aa}$ & $3.49 \mathrm{Ac}$ & $158.67 \mathrm{Aa}$ & $186.86 \mathrm{Ac}$ \\
\hline RVTC 57 & $14.43 \mathrm{Aa}$ & $14.90 \mathrm{Aa}$ & $3.94 \mathrm{Aa}$ & $3.73 \mathrm{Ac}$ & $171.77 \mathrm{Aa}$ & 199.45 Ac \\
\hline RVTC 20 & $12.51 \mathrm{Ab}$ & $13.55 \mathrm{Aa}$ & $4.05 \mathrm{Ab}$ & $5.79 \mathrm{Aa}$ & $176.83 \mathrm{Ba}$ & $309.98 \mathrm{Aa}$ \\
\hline $6889-50$ & $8.19 \mathrm{Bc}$ & $13.74 \mathrm{Aa}$ & $2.76 \mathrm{Bb}$ & $5.49 \mathrm{Aa}$ & $121.68 \mathrm{Bb}$ & $296.75 \mathrm{Aa}$ \\
\hline S. habrochaites & $10.70 \mathrm{Bb}$ & $15.69 \mathrm{Aa}$ & $2.39 \mathrm{Bb}$ & $4.50 \mathrm{Ab}$ & $204.81 \mathrm{Aa}$ & $240.85 \mathrm{Ab}$ \\
\hline S. pennellii & $3.68 \mathrm{Bd}$ & $9.49 \mathrm{Ac}$ & $0.73 \mathrm{Bc}$ & $2.39 \mathrm{Ad}$ & $32.24 \mathrm{Bc}$ & 129.23 Ad \\
\hline Cocona & $8.19 \mathrm{Ac}$ & $7.89 \mathrm{Ac}$ & $2.62 \mathrm{Ab}$ & $2.69 \mathrm{Ad}$ & $173.26 \mathrm{Aa}$ & $118.25 \mathrm{Bd}$ \\
\hline Physalis & $7.18 \mathrm{Ac}$ & $8.35 \mathrm{Ac}$ & $2.15 \mathrm{Ab}$ & $2.47 \mathrm{Ad}$ & $162.66 \mathrm{Aa}$ & $120.96 \mathrm{Bd}$ \\
\hline Control & $13.69 \mathrm{Aa}$ & $14.31 \mathrm{Aa}$ & $4.50 \mathrm{Aa}$ & $3.34 \mathrm{Bc}$ & $173.53 \mathrm{Aa}$ & $209.11 \mathrm{Ac}$ \\
\hline CV $(\%)$ & \multicolumn{2}{|c|}{11.73} & \multicolumn{2}{|c|}{15.23} & \multicolumn{2}{|c|}{12.43} \\
\hline
\end{tabular}

*Means followed by different letters, uppercase within lines and lowercase within columns, differ from each other by the Scott-Knott's test at 5\%.

Although approach grafting proved no efficiency in promoting a safe attachment at grafting point, this has the advantage of needing less control of the post-grafting environmental conditions, without inhibiting growth of seedlings during the healing period, enabling a continued growth and development of the graft root and aerial part (LEE et al., 2010; MOHAMED et al., 2014).

About the full-cleft method, great results of FA were observed only for cocona and physalis rootstocks. For this same trait and LN, RVTC 20, 6889-50 and S. pennellii stood out with successful results. As for $\mathrm{PH}$, good performances were attained by RVTC 57 and autograft through both methods, and by RVTC 20, 6889-50 and $S$. habrochaites when using approach graft (Table 2).

Analyzing SDM in both grafting methods, except for $6889-50$ and $S$. habrochaites grafted by full cleft and $S$. pennellii for both methods, the other treatments presented results equal or greater than 0.50 g. For LDM, the rootstocks RVTC 20, 6889-50, $S$. habrochaites and $S$. pennellii showed the best results; yet for and APDM/ RDM ratio, 6889-50 and S. pennellii stood out (Table 3).

Table 3. Stem dry matter (SDM), leaf dry matter (LDM) and ratio between aerial part and root dry matter (APDM/ RDM) of tomato plants grafted on distinct solanaceous via two different methods [full cleft (FC) and approach graft (AG)], on the 15 day after grafting.

\begin{tabular}{|c|c|c|c|c|c|c|}
\hline \multirow[t]{2}{*}{ Rootstocks } & \multicolumn{2}{|c|}{$\operatorname{SDM}(\mathrm{g})$} & \multicolumn{2}{|c|}{$\operatorname{LDM}(\mathrm{g})$} & \multicolumn{2}{|c|}{ APDM/ RDM } \\
\hline & $\mathrm{FC}$ & $\mathrm{AG}$ & $\mathrm{FC}$ & $\mathrm{AG}$ & $\mathrm{FC}$ & $\mathrm{AG}$ \\
\hline $0224-53$ & $0.51 \mathrm{Aa}$ & $0.50 \mathrm{Aa}$ & $0.68 \mathrm{Aa}$ & $0.66 \mathrm{Ac}$ & $2.42 \mathrm{Ac}$ & $1.98 \mathrm{Ac}$ \\
\hline RVTC 57 & $0.59 \mathrm{Aa}$ & $0.56 \mathrm{Aa}$ & $0.74 \mathrm{Aa}$ & $0.65 \mathrm{Ac}$ & $2.62 \mathrm{Ac}$ & $2.04 \mathrm{Ac}$ \\
\hline RVTC 20 & $0.56 \mathrm{Aa}$ & $0.54 \mathrm{Aa}$ & $0.73 \mathrm{Ba}$ & $1.01 \mathrm{Aa}$ & $2.50 \mathrm{Ac}$ & $2.66 \mathrm{Ac}$ \\
\hline
\end{tabular}

*Means followed by different letters, uppercase within lines and lowercase within columns, differ from each other by the Scott-Knott's test at 5\%. 
Table 3. Continuation.

\begin{tabular}{|c|c|c|c|c|c|c|}
\hline \multirow[t]{2}{*}{ Rootstocks } & \multicolumn{2}{|c|}{ SDM $(g)$} & \multicolumn{2}{|c|}{$\operatorname{LDM}(\mathrm{g})$} & \multicolumn{2}{|c|}{ APDM/ RDM } \\
\hline & $\mathrm{FC}$ & $\mathrm{AG}$ & $\mathrm{FC}$ & $\mathrm{AG}$ & $\mathrm{FC}$ & $\mathrm{AG}$ \\
\hline $6889-50$ & $0.34 \mathrm{Bb}$ & $0.55 \mathrm{Aa}$ & $0.55 \mathrm{Bb}$ & $1.06 \mathrm{Aa}$ & $3.50 \mathrm{Ba}$ & $5.25 \mathrm{Aa}$ \\
\hline S. habrochaites & $0.41 \mathrm{Bb}$ & $0.61 \mathrm{Aa}$ & $0.51 \mathrm{Bb}$ & $0.86 \mathrm{Ab}$ & $1.81 \mathrm{Ac}$ & $2.37 \mathrm{Ac}$ \\
\hline S. pennellii & $0.20 \mathrm{Bc}$ & $0.37 \mathrm{Ab}$ & $0.22 \mathrm{Bc}$ & $0.48 \mathrm{Ac}$ & $3.19 \mathrm{Bb}$ & $5.51 \mathrm{Aa}$ \\
\hline Cocona & $0.54 \mathrm{Aa}$ & $0.53 \mathrm{Aa}$ & $0.52 \mathrm{Ab}$ & $0.57 \mathrm{Ac}$ & $2.62 \mathrm{Ac}$ & $2.55 \mathrm{Ac}$ \\
\hline Physalis & $0.50 \mathrm{Aa}$ & $0.52 \mathrm{Aa}$ & $0.44 \mathrm{Ab}$ & $0.50 \mathrm{Ac}$ & $2.25 \mathrm{Ac}$ & $2.36 \mathrm{Ac}$ \\
\hline Control & $0.55 \mathrm{Aa}$ & $0.55 \mathrm{Aa}$ & $0.87 \mathrm{Aa}$ & $0.64 \mathrm{Bc}$ & $5.48 \mathrm{Aa}$ & $3.86 \mathrm{Bb}$ \\
\hline CV (\%) & \multicolumn{2}{|c|}{11.73} & \multicolumn{2}{|c|}{14.04} & \multicolumn{2}{|c|}{12.76} \\
\hline
\end{tabular}

*Means followed by different letters, uppercase within lines and lowercase within columns, differ from each other by the Scott-Knott's test at 5\%.

Superior results for LDM and APDM/ RDM ratio were found for self-grafting by cleft method in contrast to approach one. Still for the variable APDM/ RDM, self-grafting by cleft and rootstocks 6889-50 and S. pennellii grafted via approach graft showed the highest results (Table 3). In contrast, high levels of this ratio are not desirable; ideally, rootstocks with low values of this relationship are advisable, as observed for $S$. habrochaites, which showed the best balance between shoot and root development.

As stated by Neves et al. (2008), rootstocks with high volume in root system and in balance with the graft aerial part are to promote increased yield and fruit quality, taking into account the major importance of the roots in plant support and water plus nutrient absorption.

Evaluating the factors singly, we could detect that RVTC 20 showed superior results for all variables. On the other side, $S$. pennellii, cocona and physalis stood out negatively, for having inferior performance when compared to others. Additionally, we may highlight that the full-cleft graft showed better results only for GT, while for the other characteristics, grafting by approach excelled.

Interaction between grafting methods and rootstocks was also reported by Mohamed et al. (2014) in watermelon, for stem length and number of leaves; by Rizzo et al. (2004) in melon, for GT; and by Simões et al. (2014) in tomato, GT in nursery conditions; the last authors also reported that the healing of grafts have large dependence on rootstock $\mathrm{x}$ grafting method interaction.

The outstanding vegetative growth of seedlings grafted by approach method can be attributed to the keeping of root system of both plants (rootstock/ scion) after grafting. As reported by Lee et al. (2010), the approach graft leads to less stress in post-grafting whether compared to other methods, without stopping plant vegetative growth. The opposite occurs for full-cleft method, in which, for subsequent grafting, it is required to partitioning a graft branch from mother plant.
Vegetative growth changes among the different rootstock treatments may have arisen from intrinsic characteristics of each tested rootstock, being even possible that, in addition to the rootstock's favoring or not of vegetative growth, it also has an effect on crop cycle duration (MARTINS et al., 2000; PICOLOTTO et al., 2009). However, less promising results for all plant growth characteristics, after grafting, in particular for $\mathrm{LN}$ and FA, were observed when scions were grafted on S. pennellii through both methods and on cocona and physalis through approach method.

The reduced seedling growth, just after grafting, shown in both methods, for S. pennellii, impair the use of this species as rootstock, as well as seen for cocona and physalis grafted by approach method. In this sense, plant shoot undeveloped could largely reduce light interception, decreasing photosynthesis and hence production of assimilates which would interfere with crop yields (COELHO JÚNIOR et al., 2010; LUCENA et al., 2011).

Through the approach method, RVTC 20 reached interesting results for all measured traits; besides a suitable GT, this rootstock also promoted good development of the plants, after grafting, which is desirable.

Given the GT values, in general, all rootstocks, except for 6889-50, were promising for commercial production. Interestingly, despite a high GT when grafted by full cleft $(91.66 \%)$, S. pennellii should not be recommended, once provided low initial vegetative growth, underperforming the other rootstocks, in both grafting methods.

Furthermore, full-cleft method has favored cocona and physalis rootstocks for providing GT rates significantly superior compared to the other method. The approach method was effective for 0224-53, RVTC 57, RVTC 20, 6889-50 and $S$. habrochaites, with GT rates similar to those by full cleft. Besides of that, this method provided superior results for most of the traits expressing vegetative growth of seedlings. However, as reported by Lee (1994), the best method for a commercial production 
should not be chosen based on grafting success index rather than factors influencing thereof; added to this, other point must be raised as convenience, final costs and a sum of advantages and disadvantages of each for a particular producer.

Final cost of a graft is given by costs related to rootstock seedling growing and grafting operating expenses. One rootstock seedling costs nearly $\mathrm{R} \$ 0.30$ and, in both grafting methods, daily labor perform about 350 grafts. The approach method has the advantage of easy handling of seedlings after grafting (PEIL, 2003), because it demands less post-grafting control of environment conditions, being therefore the most practical and feasible for less technified farmers. Conversely, the full-cleft method requires well-planned and equipped facilities providing proper environmental conditions, such as acclimatized greenhouse and moist chambers for storing seedlings after grafting, therefore, being most used by specialized nursery farmers (LEE et al., 2010)

\section{CONCLUSIONS}

The mini-tomato accession $6889-50$ and the wild tomato species of $S$. pennellii 'LA716' are not recommended as rootstock for cultivar Santa Cruz Kada seedlings. If cocona and physalis are used as rootstocks, the full-cleft method may be recommended, and yet for rootstocks of mini-tomato 0224-53, RVTC 57 and RVTC 20, as well as the wild species $S$. habrochaites var. hirsutum 'PI-127826', the approach method would be the best one.

\section{ACKNOWLEDGMENTS}

We would like to thank Coordenação Aperfeiçoamento de Pessoal de Nível Superior (CAPES), for the support provided for this dissertation project.

To professor Dr. Derly José Henriques da Silva, from the Universidade Federal de Viçosa, for giving the minitomate accesses $0224-53$ and 6889-50 for this work.

\section{REFERENCES}

CANIZARES, K. A. L.; GOTO, R. Comparação de métodos de enxertia em pepino. Horticultura Brasileira, Brasília, v. 20, n. 1, p. 95-99, 2002.

CARDOSO, S. C. et al. Viabilidade de uso do híbrido Hawaii 7996 como porta-enxerto de cultivares comerciais de tomate. Bragantia, Campinas, v. 65, n. 1, p. 89-96, 2006.
CARRER FILHO, R. et al. Fontes de resistência múltipla à murcha de fusário em tomateiro. Pesquisa Agropecuária Brasileira, Brasília, v. 50, n. 12, p. 1225-1231, 2015.

COELHO JÚNIOR, J. M. et al. Caracterização Topográfica de Folíolos Medianos de Cultivares de Morangueiro Sob Altas Temperaturas. Revista Caatinga, Mossoró, v. 3, n. 3, p.13-18, 2010.

EASLON, H. M.; RICHARDS, J. H. Drought response in self-compatible species of tomato (Solanaceae). American Journal of Botany, Saint Louis, v. 96, n. 3, p. 605-611, 2009.

FARIAS, E. A. P. et al. Organic production of tomatoes in the amazon region by plants grafted on wild Solanum rootstocks. Ciência e Agrotecnologia, Lavras, v. 37, n. 4, p. 323-329, 2013.

FOOD AND AGRICULTURE ORGANIZATION OF THE UNITED NATIONS - FAO. Agricultural production, primary crops. 2012. Disponível em: < http://faostat.fao.org/>. Acesso em: 08 jun. 2016.

GARCIA-MARTINEZ, S. et al. Evolution of amplified length polymorphism and simple sequence repeats for tomato germplasm fingerprinting: utility for grouping closely related traditional cultivars. Genome, Birmingham, v. 49, n. 6, p. 648-656, 2005.

GILARDI, G.; GULLINO, M. L.; GARIBALDI, A. Critical aspects of grafting as a possible strategy to manage soil-borne pathogens. Scientia Horticulturae, Netherlands, v. 149, n. 1, p. 19-21, 2013.

LEE, J. M. Cultivation of grafted vegetables I: Current status, grafting methods and benefits. HortScience, Alexandria, v. 29, n. 4, p. 235-239, 1994.

LEE, J. M. et al. Current status of vegetable grafting: Diffusion, grafting techniques, automation. Scientia Horticulturae, Amsterdam, v. 127, n. 2, p. 93-105, 2010

LIN, C. et al. Application of a preliminary screen to select locally adapted resistant rootstock and soil amendment for integrated management of tomato bacterial wilt in Taiwan. Plant Disease, Saint Paul, v. 92 , n. 6 , p. 909-916, 2008

LOOS, R. A.; CALIMAN, F. R. B.; SILVA, D. J. H. Enxertia, produção e qualidade de tomateiros cultivados em ambiente protegido. Ciência Rural, Santa Maria, v. 39, n. 1, p. 232-235, 2009.

LOPES, C. A.; BOITEUX, L. S.; ESCHEMBACK, V. Eficácia relativa de porta-enxertos comerciais de 
tomateiro no controle da murcha-bacteriana. Horticultura Brasileira, Brasília, v. 33, n. 1, p. 125 130, 2015.

LUCENA, R. R. M. et al. Medição de área foliar de aceroleira. Revista Caatinga, Mossoró, v. 24, n. 2, p. 40-45, 2011.

MARTÍNEZ-BALLESTA, M. C. et al. Physiological aspects of rootstock-scion interactions. Scientia Horticulturae, Amsterdam, v. 127, n. 2, p. 112-118, 2010.

MARTINS, A. L. M. et al. Influência de portaenxertos no crescimento de clones de seringueira no Estado de São Paulo. Pesquisa Agropecuária Brasileira, Brasília, v. 35, n. 9, p. 1743-1750, 2000.

MIRANDA, B. E. C. et al. Fontes de resistência em acessos de Solanum (secção Lycopersicon) a Verticillium dahliae raças 1 e 2 . Horticultura Brasileira, Brasília, v. 28, n. 4, p. 458-465, 2010.

MOHAMED, F. H. et al. Evaluation of different grafting methods and rootstocks inwatermelon grown in Egypt. Scientia Horticulturae, Amsterdam, v. 168, n. 26, p. 145-150, 2014.

NEVES, C. S. V. J. et al. Sistema radicular de quatro porta-enxertos sob copa de tangerina Poncã. Ciência e Agrotecnologia, Lavras, v. 32, n. 2, p. 487-492, 2008.

NOGUEIRA FILHO, G. C. et al. Aspectos histológicos da união da enxertia hipocotiledonar do maracujazeiro-amarelo. Revista Brasileira de Fruticultura, Jaboticabal, v. 32, n. 2, p. 515-521, 2010.

PEIL, R. M. A enxertia na produção de mudas de hortaliças. Ciência Rural, Santa Maria, v. 33, n. 6, p. 1169-1177, 2003.

PETRAN, A.; HOOVER, E. Solanum torvum as a compatible rootstock in interspecific tomato grafting. Journal of Horticulture, Skierniewice, v. 103, n. 1, p. $1-4,2014$.

PICOLOTTO, L. et al. Características vegetativas, fenológicas e produtivas do pessegueiro cultivar Chimarrita enxertado em diferentes porta-enxertos. Pesquisa Agropecuária Brasileira, Brasília, v. 44, n. 6 , p. 583-589, 2009.

RIVARD, C. L. et al. Grafting tomato to manage bacterial wilt caused by Ralstonia solanacearum in the southeastern United States. Plant Disease, Saint Paul, v. 96, n.7, p. 973-978, 2012.

RIZZO, A. A. N. et al. Avaliação de métodos de enxertia e porta-enxertos para melão rendilhado. Horticultura Brasileira, Brasília, v. 22, n. 4, p. 808-810, 2004.

SILVA, F. A. S. ASSISTAT: Versão 7.7 beta. DEAG-CTRN-UFCG - Atualizado em 01 de abril de 2014. Disponível em: <http://www.assistat.com/>. Acesso em: 20 de maio 2014.

SIMÕES, A. C. et al. Compatibilidade de tomateiro sob diferentes porta-enxertos e métodos de enxertia em sistema orgânico. Enciclopédia Biosfera, Goiânia, v. 10, n. 18, p. 961-972, 2014.

SIRTOLI, L. F. et al. Avaliação de diferentes porta-enxertos de tomateiro cultivados em ambiente protegido. Biodiversidade, Rondonópolis, v. 7, n. 1, p. 24-28, 2008.

SIRTOLI, L. F. et al. Enxertia no desenvolvimento e qualidade de frutos de tomateiro sob diferentes porta-enxertos em cultivo protegido. Scientia Agrária Paranaensis, Marechal Cândido Rondon, v. 10, n. 3 , p. $15-22,2011$

TAM, S. M. et al. Comparative analysis of genetic diversities within tomato and pepper collections detected by retrotransposon-based SSAP, AFLP and SSR. Theoretical and Applied Genetics, New York, v. 110, n. 5, p. 819-831, 2005.

VENEMA, J. H. et al. Grafting tomato (Solanum lycopersicum) onto the rootstock of a high-altitude accession of Solanum habrochaites improves suboptimal-temperature tolerance. Environmental and Experimental Botany, Oxford, v. 63, n. 1, p. $359-367,2008$

WREGE, M. S. et al. Atlas climático da Região Sul do Brasil: Estados do Paraná, Santa Catarina e Rio Grande do Sul. 1. ed. Pelotas, RS: Embrapa Clima Temperado, 2011.336 p. 